VERESNYUK N., PYROHOVA V., MISIURA A., MALACHYNSKA M. Department of Obstetrics, Gynecology and Perinatology, Postgraduate Faculty, Danylo Halytsky Lviv National Medical University, Lviv, Ukraine

\title{
UNICORNUATE UTERUS WITH FUNCTIONAL RUDIMENTARY HORN: CLINICAL MANIFESTATIONS AND DIAGNOSTIC PROBLEMS (CLINICAL CASE)
}

\begin{abstract}
A unicornuate uterus ranges from 1 in 1000 to 1 in 5400 women and 74-90\% of them will have rudimentary uterine horn. Patients with non-communicating uterine horns that contain functional endometrium are at an increased risk of ectopic pregnancy, hematometra, hematosalpinx, endometriosis and poor pregnancy outcomes. This report describes a case of a successful pregnancy in non-communicating rudimentary horn of unicornuate uterus and postpartum clinical manifestation of it and difficulties of differential diagnosis of uterus anomalies.
\end{abstract}

Keywords: unicornuate uterus, pregnancy, hematometra.

The unicornuate uterus results from the normal development of one Müllerian duct and absent or incomplete development of the contralateral duct. The prevalence of this kind of uterine malformations accounts for 2.4 to $13 \%$ of all Müllerian anomalies [1]. In most of cases, the rudimentary horn is noncommunicating and often associated with ectopic pregnancies. It occurs in approximately 1 out of 76,000 pregnancies to 1 per 150,000 . The risk of uterine rupture is approximately $80 \%$ occurring by the end of the second trimester [2]. The unicornuate uterus with a noncommunicating rudimentary horn may be associated with gynecological and obstetric complications such as infertility, endometriosis, hematometra, urinary tract anomalies, abortions, and preterm deliveries [1]. Pregnant women with unicornuate uterus are group of a high-risk of the complications' development [3, 4].

\section{CASE REPORT AND DISCUSSION}

We report a case of a successful pregnancy in non-communicating rudimentary horn of unicornuate uterus and postpartum clinical manifestation of it.

A 32-year-old woman came to our center with a history of severe cyclic secondary dysmenorrhea since 10 months which had now become intolerable. The dysmenorrhea severty by visual analogue scale for pain score was eight. She had been taking non-steroidal anti-inflammatory medications on and off, which were not relieving the pain. Moreover, the patient tried to become pregnant for two years.

She was married for 11 years. Her menstrual cycles were regular. No history of pelvic inflammatory disorder. She had no bowel or bladder complaints. The first time uterine anomaly was diagnosed by twodimensional (2D) ultrasound seven years ago. It was classified as a uterus bicornis. The patient could not become pregnancy for five years. She had undergone hysterolaparoscopy for evaluation of case of infertility in 2013, where uterus bicornis with decreasing size of right horn was diagnosed (uterus anomaly was not classified correctly) and the coagulation of endometriosis of right ligamentum sacro-uterine was performed. The patient's left tube during the chromosalpingoscopy was possable unlike the right one. However, no information about rudimentary horn and its communication with the main horn was reported in her surgical record. The pregnancy became two month later. At the first screening ultrasound, the pregnancy was diagnosed in the right horn. No pregnancy complications were reported to 33 weeks. The patient informed that she regularly attended the routine antenatal care provided in her hometown's health unit but she was not said about the risk of a rudimentary horn rupture due to misdiagnosis of uterus anomaly. The patient was transferred to a tertiary referral hospital with the pregnancy-induced hypertension and intrauterine growth restriction - the fetal size and weight were lower considering the gestational age which was 33-34 weeks and uterus anomaly (uterus duplex uni colli). Obstetric ultrasound examinations at the third trimester of her pregnancy showed a normal insertion of the placenta, low amniotic fluid index and breech fetal presentation. On speculum examination normal vagina with a single cervix were seen. A serial 
growth ultrasound examination performing until 36 weeks and 4 days' gestation confirmed a low baby weight.

At 37 weeks' pregnancy, the patient underwent an urgent cesarean section because of fetal distress and she had a healthy baby girl, with an Apgar score of 6 to 7, weight of $1980 \mathrm{~g}$ and height of $47 \mathrm{~cm}$. During the surgery, unexpectedly no communication with another horn was found. Both her ovaries and tubes were normal. The volume of surgery was limited to caesarean section with drainage of the abdominal cavity.

The mother had hyperthermia during the week after surgery, there were lochia absent from the vagina. Seria ultrasound examinations in the postsurgery period showed decrising sizes of hematometra in the right rudimentary horn. At day 8 after cesarean section, the patient was discharged home.

After 4 years, the patient came to the Municipal Non-profit Enterprises of Lviv Regional Council «Lviv Regional Center of reproductive health» with complaints of dysmenorrhea and secondary infertility that were described before.
An ultrasound examination, including an baseline 2D) ultrasound assessment of pelvis organs with the following three-dimensional (3D) transvaginal scan of uterus, was performed. The investigation showed a left unicornuate uterus of the dimensions of $44 \mathrm{~mm} \times 32 \mathrm{~mm} \times 38 \mathrm{~mm}$ with an normal endometrial thickness. At the right side, a non-communicating rudimentary horn with hematometra of the sizes of $31 \mathrm{~mm} \times 15 \mathrm{~mm}$ and postcesarean scar was described (Class U4a according to the ESHRE/ESGE classification 2013). In addition, hydrosalpinx and endometrioid cyst were diagnosed at the right side. The ultrasonography of kidneys did not detect any deviation. Hysterosalpingography showed the leftside unicornuate uterus with normal passable left tube.

Magnetic resonance imaging without intravenous contrast was performed. The images through the level of the pelvis demonstrated a left sided unicornuate uterus with a single vagina and a single cervix. The right non-communicating horn contained hematometra. Furthermore, small cysts were found in the right ovary (Fig. 1).

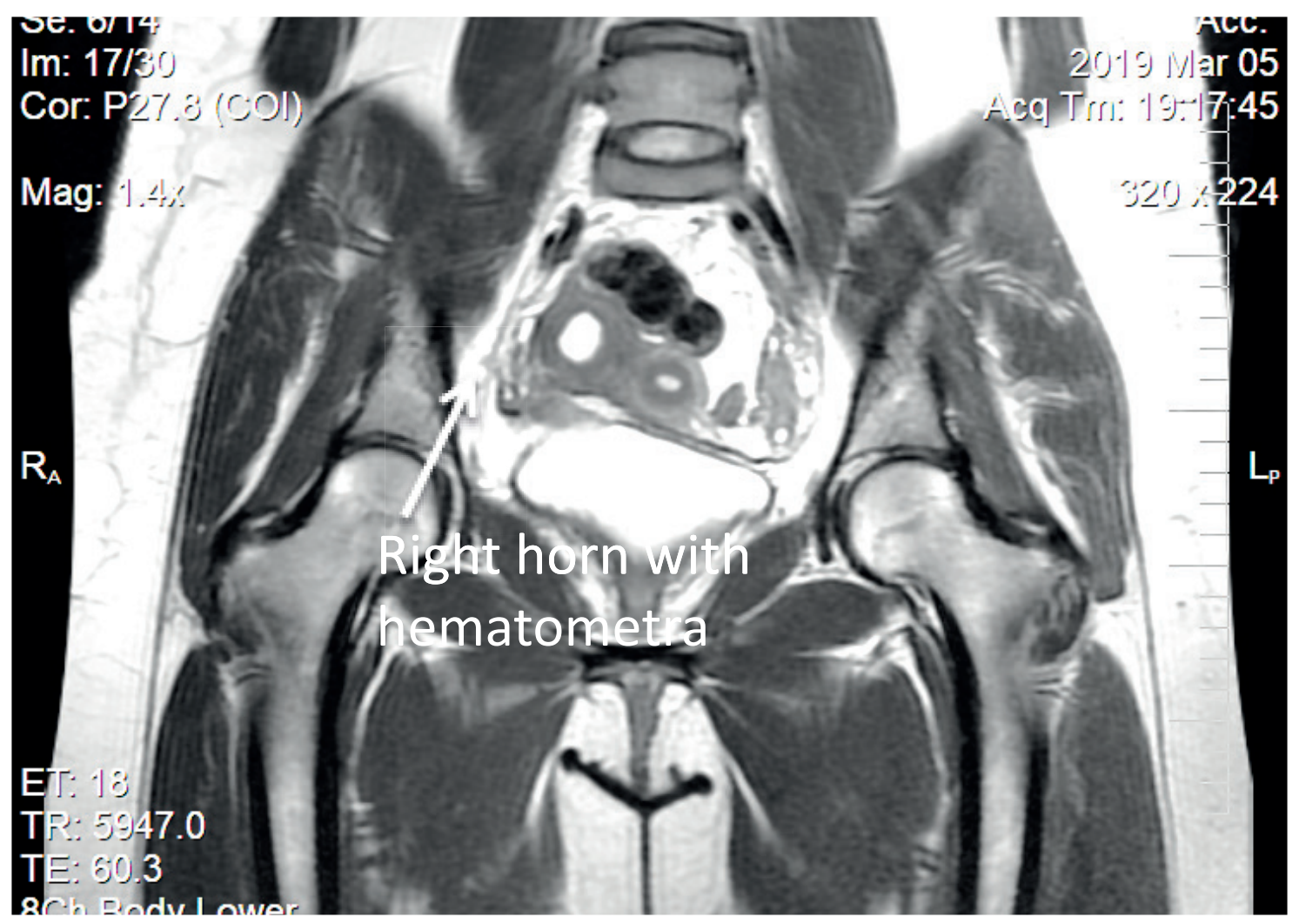

Fig. 1. The MRI imagine shows left unicornuate uterus and right rudimentary horn with hematometra

Because the presence of a hematometra in the rudimentary horn and severe secondary dysmenorrhea the surgical treatment was indicated (Fig. 2). Remov- al of right rudimentary horn, rightsided salpingectomy and resection of right ovary were performed through laparotomy. 


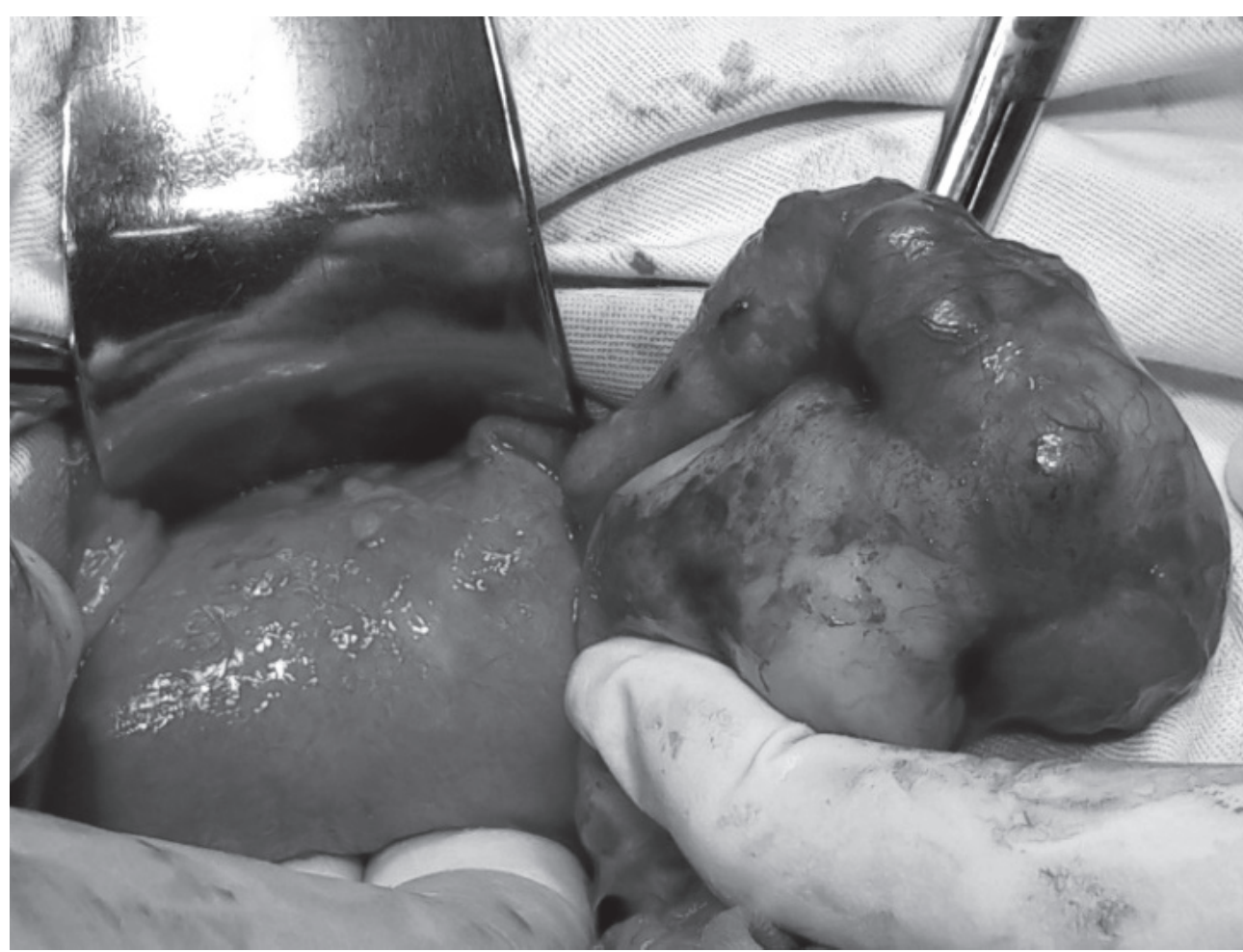

Fig. 2. Intraoperative photograph showing the right non-communicating horn with hematosalpinx of right fallopian tube and right ovary with endometrioid cyst

After the cut of the removed rudimentary horn dark blood poured out of it (Fig.3).

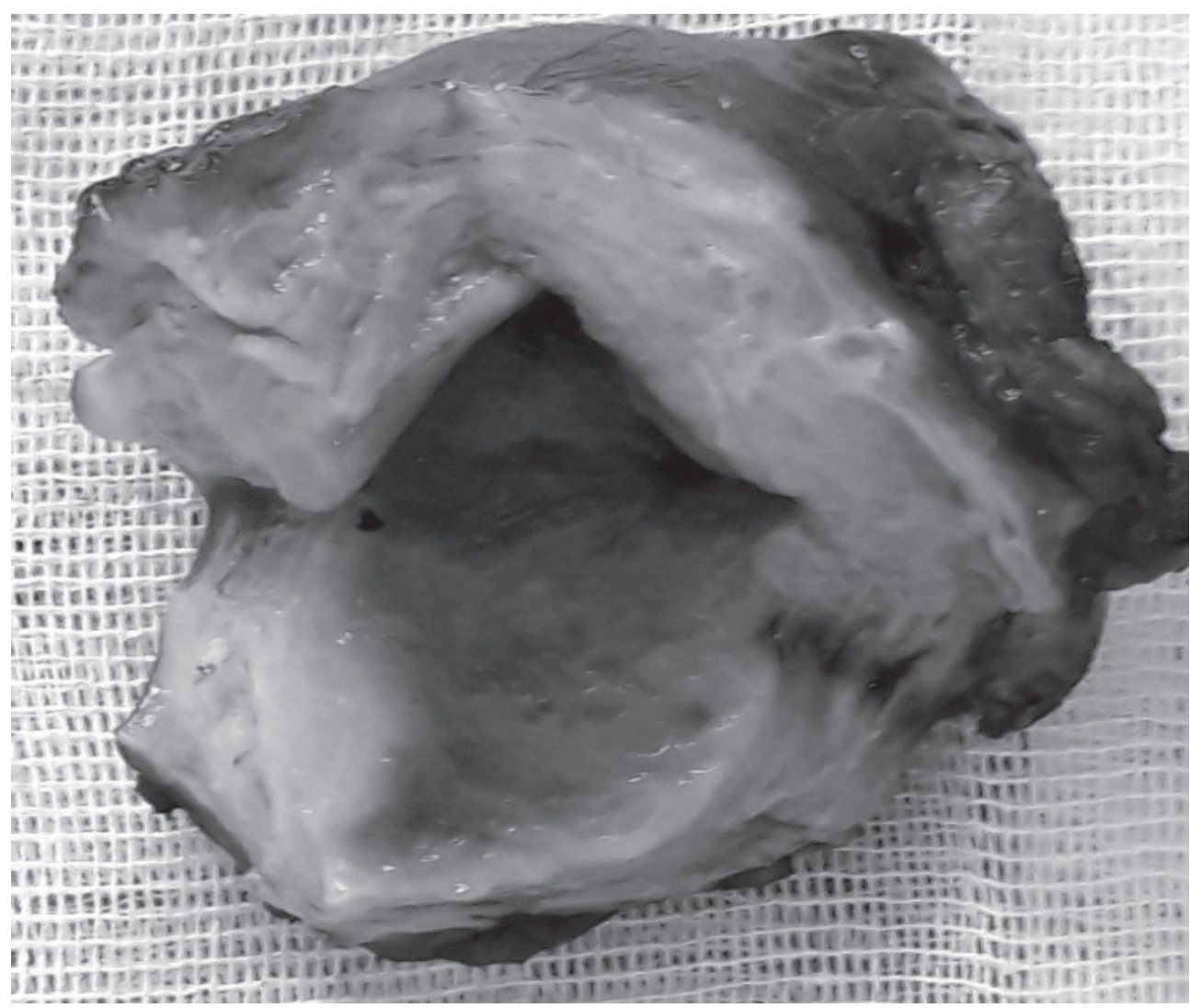

Fig.3. Removed rudimentary horn

Histological examination showed adenomyosis of the uterine horn, endometrioid cyst of the ova- ry, hematosalpinx and endometriosis of the removed right fallopian tube. The patient had a good postop- 
erative recovery and she became completely painfree postoperatively.

Depending on the subclass, unicornuate uterus may have a different impact on patients' symptoms and reproductive outcomes. However, the real prevalence of the unicornuate uterus is unknown because of many women never complain any symptoms due to the non-functional horn or absent of it. The ESHRE/ESGE classification system helps to divide uterine anomalies into classes and subclasses according to increasing severity of the anatomical deviation and clinical manifestations [5]. Class U4 includes hemi-uterus with the contralateral part incompletely formed or absent. Class U4 is divided into two sub-classes: class U4a or hemiuterus with a rudimentary (functional) cavity; class $\mathrm{U} 4 \mathrm{~b}$ or hemi-uterus without a rudimentary (functional) cavity is characterized either by the presence of a nonfunctional contralateral uterine horn or by aplasia of the contralateral part [5]. 3D ultrasound has been shown to be accurate in the diagnosis of uterine malformations. Our case was class $\mathrm{U} 4 \mathrm{aC} 0 \mathrm{~V} 0$, as the patient had a functional cavity, allowing pregnancy, normal cervix and vagina. Unicornuate uterus is often combined with renal anomalies although we did not diagnose any renal pathology in case which was described [6]. So renal ultrasound must be recommended to patients with uterus anomalies.

In our case, the pregnancy became in noncommunicating rudimentary horn. According to the literature, it was possible by transperineal migration of sperm or fertilized ovum $[1,7]$. Pregnancy in noncommunicating rudimentary horn may be associated with serious pregnancy-related complications but this case was an exeption [8]. Only some cases of succesessful pregnancy in the non-communicating rudimentary horn are described. That is why when pregnancy in the rudimentary horn is diagnosed, to prevent a life-threatening uterine rupture, immediate surgery is recommended [1, 2, 7].

Our case demonstrated the increasing of dysmenorrhea's severty and sizes of hematometra only after partum. Surgical resection of a functional rudimentary horn is recommended even if the horn is communicating, whether the woman is pregnant or not $[2,7]$. The basic purpose of surgery is pain relief and hence better quality of life what was demonstrated in this case.

\section{CONCLUSIONS}

The diagnosis and the management of the rudimentary uterine horn are often a challenge. Patients affected by dysmenorrhea and chronic pelvic pain should always be screend with 2D and 3D ultrasound examinations by highexperienced specialist. Complete removal of a communicating or non-communicating functional rudimentary horn with or without pregnancy in it is always recommended to prevent menstrual and pregnancy complications.

\section{REFERENCES}

1. Sánchez-Ferrer ML, Prieto-Sanchez MT, Sánchez Del Campo F. Variations in clinical presentation of unicornuate uterus with non-communicating rudimentary horn (class IIB of the American Fertility Society classification). Taiwan J Obstet Gynecol. 2018;57(1):110-114.

2. Blancafort C, Graupera B, Pascual MÀ, Hereter L, Browne JL, Cusidó MT. Diagnosis and laparoscopic management of a rudimentary horn pregnancy: Role of three-dimensional ultrasound. J Clin Ultrasound. 2017;45(2):112-115.

3. Pados G, Tsolakidis D, Athanatos D, Almaloglou K, Nikolaidis N, Tarlatzis B. Reproductive and obstetric outcome after laparoscopic excision of functional, noncommunicating broadly attached rudimentary horn: a case series. Eur J Obstet Gynecol Reprod Biol. 2014 Nov; $182: 33-7$.

4. Caserta D, Mallozzi M, Meldolesi C, Bianchi P, Moscarini M Pregnancy in a unicornuate uterus: a case report. J Med Case Rep. 2014;8:130.

5. Grimbizis GF, Gordts S, Di Spiezio Sardo A, et al. The ESHRE/ESGE consensus on the classification of female genital tract congenital anomalies. Hum Reprod. 2013;28(8):2032-2044.

6. Khati NJ, Frazier AA, Brindle KA. The unicornuate uterus and its variants: clinical presentation, imaging findings, and associated complications. J Ultrasound Med. 2012 Feb;31(2):319-31.

7. Li X, Peng P, Liu X, Chen W, Liu J, Yang J, Bian X. The pregnancy outcomes of patients with rudimentary uterine horn: A 30-year experience. PLoS One. 2019;14(1): e0210788.

8. Dhar H. Ruptured rudimentary horn at 22 weeks. Niger Med J. 2012 Jul-Sep; 53(3): 175-177.

\section{СПИСОК ЛІТЕРАТУРИ}

1. Sánchez-Ferrer ML. Variations in clinical presentation 
of unicornuate uterus with non-communicating rudimentary horn (class IIB of the American Fertility Society classification) / ML. Sánchez-Ferrer, MT. PrietoSanchez, F. Sánchez Del Campo // Taiwan J Obstet Gynecol. - 2018. - Vol. 57(1). - P.110-114.

2. Diagnosis and laparoscopic management of a rudimentary horn pregnancy: Role of three-dimensional ultrasound / C. Blancafort, B. Graupera, MÀ. Pascual [et al.] // J Clin Ultrasound. - 2017. - Vol.45, №2. - P.112115 .

3. Reproductive and obstetric outcome after laparoscopic excision of functional, non-communicating broadly attached rudimentary horn: a case series / G. Pados, D. Tsolakidis, D. Athanatos [et al.] // Eur J Obstet Gynecol Reprod Biol. - 2014. - Vol.182. - P. 33-7.

4. Pregnancy in a unicornuate uterus: a case report / D.Caserta, M. Mallozzi, C.Meldolesi [et al.] // J Med Case Rep. - 2014. - Vol. 8. - P.130.

5. The ESHRE/ESGE consensus on the classification of female genital tract congenital anomalies / GF. Grimbizis, S. Gordts, A. Di Spiezio Sardo [et al.] // Hum Reprod. 2013. - Vol. 28, №8. - P. 2032-2044.

6. Khati NJ. The unicornuate uterus and its variants: clinical presentation, imaging findings, and associated complications / NJ. Khati, AA. Frazier, KA. Brindle // J Ultrasound Med. - 2012. - Vol. 31, №2. - P. 319-31.

7. The pregnancy outcomes of patients with rudimentary uterine horn: A 30-year experience / X. Li, P. Peng, X. Liu [et al.] // PLoS One. - 2019. - Vol.14(1): e0210788.

8. Dhar H. Ruptured rudimentary horn at 22 weeks / H.Dhar // Niger Med J. - 2012. - Vol. 53, №3. - P. 175-177.

\section{Ethical Approval}

The articles does not contain any studies with human participants performed by any of the autors.

\section{Conflict of interest}

Nataliya Veresnyuk, Vira Pyrohova, Angela Misiura have no conflicts of interest. There is no funding sourseassociated with this study.

\section{PЕЗЮМЕ}

\section{ФУНКЦІОНУЮЧИМ РУДИМЕНТАРНИМ РОГОМ: КЛІНІЧНІ ПРОЯВИ ТА ПРОБЛЕМИ ДІАГНОСТИКИ (клінічний випадок)}

ВЕРЕСНЮК Н.С., ПИРОГОВА В.І., МІСЮРА А.Г., МАЛАЧИНСЬКА М.Й.

Частота однорогої матки коливається від 1 на
1000 до 1 на 5400 жінок, а 74-90\% 3 них мають рудиментарний матковий ріг. Пацієнтки 3 рудиментарним рогом матки, який не сполучається $з$ основним рогом матки і містить функціональний ендометрій, мають підвищений ризик позаматкової вагітності, гематометри, гематосальпінкса, ендометріозу та негативні репродуктивні наслідки. Ця публікація описує випадок успішної вагітності в рудиментарному розі однорогої матки, який не сполучається 3 основним, клінічні прояви після пологів та труднощі диференційної діагностики маткових аномалій.

Ключові слова: однорога матка, вагітність, гематометра.

\section{PE3ЮМЕ}

\section{ОДНОРОГАЯ МАТКА С ФУНКЦИОНИРУЮЩИМ РУДИМЕНТАРНЫМ РОГОМ: КЛИНИЧЕСКИЕ ПРОЯВЛЕНИЯ И ПРОБЛЕМЫ ДИАГНОСТИКИ (клинический случай)}

ВЕРЕСНЮК Н.С., ПИРОГОВА В.И., МИСЮРА А.Г., МАЛАЧИНСКАЯ М.Й.

Частота однорогой матки колеблется от 1 на 1000 до 1 на 5400 женщин, а 74-90\% из них имеют рудиментарный маточный рог. Пациентки с рудиментарным рогом матки, который не сообщается с основным рогом матки и содержит функционирующий эндометрий, имеют повышенный риск внематочной беременности, гематометры, гематосальпинкса, эндометриоза и негативные репродуктивные последствия. Эта публикация описывает случай успешной беременности в рудиментарном роге однорогой матки, который не сообщается с основным, клинические проявления после родов и трудности дифференциальной диагностики маточных аномалий.

Ключевые слова: однорогая матка, беременность, гематометра. 